\title{
The Impact of Market Timing on European Firms' Capital Structure: RLBOs vs. IPOs
}

\author{
Fadoua Kouki ${ }^{1}$ \\ ${ }^{1}$ Department of Finance and Banking, Community College, King Khalid University, Abha, Saudi Arabia \\ Correspondence: Fadoua Kouki, Assistant Professor, Department of Finance and Banking, Community College, \\ King Khalid University, Abha, Saudi Arabia.
}

Received: August 28, 2020

Accepted: October 30, 2020

Online Published: January 14, 2021

doi:10.5430/ijfr.v12n2p219

URL: https://doi.org/10.5430/ijfr.v12n2p219

\begin{abstract}
Our study compares the impact of market timing on the capital structure of reverse leveraged buyouts (RLBOs) and initial public offerings (IPOs). Our sample is made up of 210 RLBOs and 210 public companies listed between 1995 and 2015 and linked by size (turnover) and industry (based on the first two digits of the SIC code). Our results show that the impact of market timing measures on capital structure is different between RLBOs and public companies. In accordance with Baker and Wurgler (2002) and others, these measures have a negative and significant effect on the capital structure of the two types of companies. This significance is persistent ten years after the IPO for public companies and only three years after the IPO for RLBOs. RLBOs rebalance the market timing effect on their capital structures much more quickly and therefore move toward the target debt ratio more quickly than their counterparts. These results challenge the robustness and generality of Baker and Wurgler's (2002) market timing theory. The capital structure of RLBOs seems to be better explained by the characteristic variables of companies suggested by the theory of trade-off.
\end{abstract}

Keywords: market timing theory, capital structure, RLBOs

\section{Introduction}

(Baker and Wurgler, 2002) linked market timing to the capital structure and found that the practice of market timing has lasting effects on the capital structure. Therefore, they set out the theory of market timing, which predicts that the financial structure of a company results not from the conscious choice of a target ratio but rather from the accumulation of decisions taken in the past according to the stock market context.

The discovery of the market timing lasting impact on financial leverage is incompatible with the static trade-off theory. It predicts that the value of the business is maximized when the business reaches an optimal leverage ratio, which is the product of the combination of the anticipated debt bankruptcy costs and tax benefits. The static trade-off theory predicts that the characteristics of a company define its capital structure, and it does not predict any cumulative effect of previous financial decisions on the current leverage of the company.

The works of (Baker and Wurgler, 2002) launched a new wave of debate in the search for the capital structure. Thus, the central question was how the market timing as a previous funding decision, affects the capital structure. The theory of static trade-off suggests that companies rebalance their leverage ratios to reach the target whenever shocks cause deviations from it. Therefore, previous funding decisions are not expected to have a durable impact on the capital structure. However, the theory of market timing, proposes that firms don't have to rebalance the impact of previous issues because they don't have an optimal debt ratio.

Indeed, (Huang and Ritter, 2009) supported the market timing hypotheses by demonstrating that historical issues of securities affected by equity risk premiums influence the capital structure in the long term and that companies adjust very slowly toward target debt. (Doukas et al., 2011) examined the reasons for debt issuance during hot periods of the debt market and their impact on the capital structure. They found that market timing and information asymmetry are important factors that lead companies to issue much more debt during hot market periods than during cold periods.

However, little research contradicts Baker and Wurgler's conclusions about the lingering impact of market timing on the capital structure. Indeed, (Hovakimian, 2006) showed that growth opportunities that are not captured by the 
current market-to-book (M/B) ratio cause the results of (Baker and Wurgler, 2002). By supporting this point of view, (Kayhan and Titman, 2007) demonstrated that the importance of (Baker and Wurgler, 2002) measure could be explained in large part by the fact that historical M/B ratios can capture other determinants of the choice of structure capital, such as growth opportunities. (Bruinshoofd and Haan, 2012) noted in their study that the M/B ratios and the debt of the company are negatively correlated in the case of American companies, unlike those in the United Kingdom and Continental Europe. (Alti, 2006) and (Leary and Roberts, 2005) indicated that American companies have dynamically rebalanced their debt to be in the most advantageous assortment so that the impact of market timing is transient. The persistence of the impact of market timing has been questioned by many other studies. For example, (Hovakimian, 2006), (Alti, 2006), (Leary and Roberts, 2005), (Flannery and Rangan, 2006), and (Kayhan and Titman, 2007) confirmed that even if market timing exists, its impact on businesses does not remain over the long term, and they also showed that companies rebalance their debt ratios toward several targets.

The research mentioned above relates only to public companies, yet no consensus has been achieved. A study that extends to other types of companies could probably be useful to test the generality and robustness of the theory of market timing. Questioning the general validity of this theory in the case of public companies leads us to wonder whether the theory is verified in the case of reverse leveraged buyouts (RLBOs) given the particularity of their capital structure. This means that a comparative study between public European companies and European RLBOs is required.

Presumably, market timing should have different repercussions on the capital structure of both types of businesses since their capital structures and tax structures are different. If our hypothesis is verified, this will further question the generality of the market timing theory.

Our study is of great empirical contribution in questioning the generality and the empirical validity of the theory of market timing. In fact, to our knowledge, it represents the only study that examines the robustness of this theory in the case of private equity companies especially RLBOs.

The remainder of the paper proceeds as follows: The second section reviews the market timing theory literature. The third section provides an overview of the main data as well as the methodology used, specifying the different hypotheses of our study. The fourth section presents detailed findings from our data analysis and discusses possible reasons for the variation in the impact of market timing on the capital structure. The final section summarizes our key conclusions.

\section{Market Timing Theory}

According to (Baker and Wurgler, 2002), market timing has a great impact on the performance of the company when choosing the appropriate financial structure. Companies' financial preferences reflect the results of previous changes in their stock prices and their ability to anticipate the market. Certainly, managers grasp favorable circumstances to issue shares to reduce the use of debt and thus amplify the opportunity for its retrenchment throughout the market expansion phase. When the financial market is not very promising, corresponding to a rigorous control implemented by the mass of shareholders, the agents will be limited to the requirements as well as the restrictions imposed by the market. That is to say, they will be looking for less risky debt. The pecking order and static trade-off hypotheses have always been challenged by the theory of market timing in the context of the criticisms of (Baker and Wurgler, 2002) linking the M/B ratios to the capital structure. Baker and Wurgler's argument that securities issued over a year have prolonged effects on the capital structure has been challenged by a series of more recent documents.

Business leaders seem to link their funding decisions to market timing. According to a survey by (Graham and Harvey, 2001), two-thirds of business leaders believe that the amount of overvaluation or undervaluation of their securities is a major determinant of their issuance decisions and securities. The distinction between the market timing theory and the pecking order theory is based on a semi-strong form of financial market efficiency.

Indeed, the pecking order theory predicts that because of semi-strong market efficiency, declaring securities is the best approximation of the extent of information irregularity. However, the market timing theory does not depend on the claim that market efficiency is semi-strong. Indeed, windows of opportunity exist when the relative cost of equity presents a difference over time for logical or illogical reasons. (Altı and Sulaeman, 2012) showed in their study that this timing behavior is exhibited by companies in response to higher returns that occur following strong demand for investment by institutions.

On the other hand, (Chen et al., 2013) supported neither the pecking order theory (persistence of the results of (Frank and Goyal, 2003)) nor the empirical results of adverse selection, and they showed that the authentication of the market timing theory is verified for the Taiwan Stock Exchange (TSM), mainly from 1990 to 2001. However, during 
the 2002-2005 phase, the application of the market timing theory was not appropriate. In other words, according to (Chen et al., 2013), companies in Taiwan favor the use of additional debt rather than the issuance of securities when market performance declines. The same result was obtained by (Zavertiaeva and Nechaeva, 2017).

In the circumstances of the securities issue, (Hovakimian, 2004) and (Kayhan and Titman, 2007) maintained the fact of the existence of market timing. However, they all disagreed with Wurgler and Baker on the lingering impact of market timing on the capital structure. (Alti, 2006) and (Leary and Roberts, 2005) indicated that American companies have dynamically rebalanced their debt to be in the most advantageous assortment so that the impact of market timing is transient.

The persistence of the impact of market timing has been questioned by many other studies. For example, (Hovakimian, 2006), (Alti, 2006), (Leary and Roberts, 2005), (Flannery and Rangan, 2006), (Kayhan and Titman, 2007) confirmed that even if market timing exists, its impact on businesses does not remain over the long term, and they also showed that companies rebalance their debt ratios toward several targets. (Chen and Zhao, 2006), (Huang and Ritter, 2009), (Chang and Dasgupta, 2009) found eloquent evidence of market timing and raised questions about the interpretation of target ratios.

\section{Methodology}

This section will be devoted to the presentation of the main data as well as the methodology used, specifying the different hypotheses of our study.

\subsection{Presentation of the Main Data Used}

Our sample is made up of 210 RLBOs listed between 1995 and 2015 as well as 210 public companies listed between 1995 and 2015 and linked to RLBOs by size (turnover) and industry (based on the first two digits of the SIC code). Our study period begins in 1995 because this year corresponds in particular to the period of the unwinding of the first LBOs that appeared in Europe at the end of the 1980s, especially in the United Kingdom. Our sample focuses exclusively on three European countries: the United Kingdom, France, and Germany.

We obtained our sample from two databases: Thomson One Banker and SDC Platinum. The data of some RLBOs obtained from the Thomson One Banker database was not complete. So, we collected them from the SDC Platinum database. When data was definitively unavailable, we preferred to exclude these RLBOs from our sample. The merger of the two databases allowed us to obtain a sample of 277 RLBOs between 1995 and 2015. The data of public companies were collected from the Thomson One Banker database.

The accounting and stock market data was obtained from the Worldscope Fundamental Data database (Thomson Financial). We encountered certain difficulties in retrieving the historical accounting and stock market data of the oldest RLBOs in our sample, the majority of which have disappeared from the stock market. When this data was definitively unavailable, we preferred to exclude these companies from our sample, which was reduced to 210 RLBOs between 1995 and 2015.

\subsection{Methodology}

\subsubsection{Market Timing}

Several studies have focused on market timing. The most direct evidence is the study of (Graham and Harvey, 2001), who found that two-thirds of CFOs admit that undervaluation is one of the most important determinants regarding the financial choices of different companies. The literature also shows that IPOs and SEOs coincide with an overvaluation of the market. Their long-term underperformance is also interpreted as proof of market timing.

The effect of the market-to-book ratio on the number of shares issued will be directly tested to examine whether companies take advantage of the relatively lower costs of issuing shares during an overvaluation of the market to raise more equity. (Chen and Zhao, 2006) studied the role of the market-to-book ratio in financing decisions. They have proven that companies are more likely to issue shares when their market-to-book ratios are high to take advantage of low external financing costs.

To study the relationship between the number of shares issued and changes in market value, the net share issue is regressed on the market-to-book ratio. We expected a positive relationship. To solve the variation problem of market values across industries, a M/B ratio relative to the median $\mathrm{M} / \mathrm{B}$ industry ratio (RelM/B) will be used to replace the $\mathrm{M} / \mathrm{B}$ ratio. RelM/B measures the decline or increase in the company's M/B ratio compared with its industry peers. A higher RelM/B indicates a high market value of the business and potentially an overvaluation. 


\subsubsection{The Market Timing Effect on Debt}

We examine the significance of the market timing effect on the capital structure of the companies in our two samples, namely, RLBOs and public companies. If the static trade-off theory explains the capital structure of a company, whenever the debt ratio deviates from its optimal level, the company must adjust it to reach its target debt ratio. Then, we cannot detect a lasting effect of market timing on the company's capital structure.

To study the relationship between market timing and leverage, we regress the financial leverage ratio for the current year on $\mathrm{MB}_{\text {efwa }}$ and the determinants of capital structure used by previous research ((Rajan and Zingales, 1995); (Booth et al., 2001)). These determinants are the M/B ratio, profitability (EBITDA/A), size $(\log (\mathrm{S}))$, and tangibility (PPE/A).

$$
L_{t}=\alpha_{0}+\alpha_{1} M B_{\text {efwa } ;-1}+\alpha_{2}\left(\frac{M}{B}\right)_{\mathrm{t}-1}+\alpha_{3}\left(\frac{E B I T D A}{A}\right)_{\mathrm{t}-1}+\alpha_{4} \log (\mathrm{S})_{\mathrm{t}-1}+\alpha_{5}\left(\frac{P P E}{A}\right)_{\mathrm{t}-1}+\varepsilon_{\mathrm{t}}
$$

Like (Baker and Wurgler, 2002), we employ the average M/B ratio weighted by external financing $\left(\mathrm{MB}_{\text {efwa }}\right)$ as a market timing measure to test the validity of the market timing theory.

The measure of market timing is as follows:

$$
\mathrm{MB}_{\text {efwa }, \mathrm{t}}=\sum_{s=0}^{t-1} \frac{e_{S}+d_{s}}{\sum_{r=0}^{t-1}\left(e_{r}+d_{r}\right)} *\left(\frac{M}{B}\right)
$$

Where "e" and "d" respectively represent the net issuance of debt and the net issuance of equity and the summations are calculated from the IPO year to the year $\mathrm{t}-1$ to avoid collinearity. The time index $\mathrm{s}$ and $\mathrm{r}$ go from the IPO year to $\mathrm{t}-1$.

$\sum_{s=0}^{t-1} \frac{e_{S}+d_{s}}{\sum_{r=0}^{t-1}\left(e_{r}+d_{r}\right)}$ is the ratio of external funding for the current period to total external funding for the study period.

A highest $\mathrm{M} / \mathrm{B}$ ratio gives more scope to a high market valuation. So that, if a company raises external funds $\mathrm{MB}_{\text {efwa,t }}$ takes on a greater value. Obtaining a significant coefficient further supports the theory of traditional static trade-off.

Table 1. Definitions of variables used

\begin{tabular}{lll}
\hline Variable & Definition & $\begin{array}{l}\text { The } \\
\text { used in the text }\end{array}$ \\
\hline Total assets & Total assets & $\mathrm{A}$ \\
\hline $\begin{array}{l}\text { Market value } \\
\text { assets }\end{array}$ & of & $\mathrm{M}$ \\
\hline Market equity & Common shares outstanding multiplied by share price & \\
\hline Book leverage & book debt divided by (book debt plus book equity) & D/IC \\
\hline Market leverage & book debt divided by market value of assets & D/M \\
\hline $\begin{array}{l}\text { Market-to-book } \\
\text { ratio }\end{array}$ & market value of equity divided by book value of equity & M/B \\
\hline Profitability & $\begin{array}{l}\text { Earnings before interest, taxes, and depreciation divided by total } \\
\text { assets }\end{array}$ & EBITDA/A \\
\hline Size & logarithm of net sales & log(S) \\
\hline Tangibility & Net property, plant and equipment divided by total assets & PPE/A \\
\hline Net debt issues & variation in book debt divided by invested capital & $\mathrm{d}$ \\
\hline Net equity issues & $\begin{array}{l}\text { (variation in book equity minus variation in retained earnings) } \\
\text { divided by invested capital }\end{array}$ & $\mathrm{e}$ \\
\hline
\end{tabular}

Note: The table shows the list of variables used in the study with their definitions 
We retain the M/B ratio, which represents the ratio of the market value of equity to its book value, as a measure of growth opportunities in our analysis. The more the company's growth dynamics are important, the more the firm faces financing problems.

According to (Myers, 1984), past and present profitability affects the company's capital structure. This relationship has been the subject of theoretical controversy. According to the theory of static trade-off, profitability positively affects the debt level of the company. This report is explained by the fact that a profitable company has an interest in contracting a debt because the financial costs will be deductible from its tax result. Also, if past and present profitability reflect future profitability, a highly profitable enterprise will be able to repay its debts ((Shyam-Sunder and C. Myers, 1999); (Elsas et al., 2014)). The static trade-off theory, therefore, predicts a positive relationship between debt and profitability. However, several researchers found a strong negative correlation between debt and profitability, which implies that the most profitable firms have lower leverage ratios. This result is consistent with the pecking order theory ((Rajan and Zingales, 1995); (Berger et al., 1997); (Köksal and Orman, 2015)).

In our analysis, profitability is represented by the ratio between earnings before interest, taxes, depreciation, and amortization (EBITDA) and total assets ((Booth et al., 2001), (Huang and Song, 2006)). A negative coefficient of the ratio (EBITDA/total assets) will be compatible with the assumption that the most profitable companies have large internal funds and therefore require less debt.

The criterion adopted to measure the size of a company is often the turnover, the balance sheet total, or the number of employees. Several researchers have proven that company size is one of the most important factors in the financial choices of companies ((Harris and Raviv, 1991);(Rajan and Zingales, 1995)).

According to several studies, a positive relationship exists between company size and leverage. Indeed, according to (Warner, 1977), the economies of scale in bankruptcy costs are negatively proportional to the size of the business because the diversification of activities reduces the volatility of business performance. It follows that large firms have greater debt capacity. Several studies (Booth et al., 2001);(Wiwattanakantang, 1999);(Köksal and Orman, 2015)) confirmed the positive relationship between debt and size.

Tangible fixed assets have an impact on the level of indebtedness of the company because they are less concerned with information asymmetry and loss, in the event of disposal, less value than intangible fixed assets. They, therefore, constitute guarantees to bondholders. The filing of real guarantees sends a positive signal to creditors because they can exercise these guarantees in the event of insolvency. (Scott, 1977) showed that a company can increase the value of these stocks by issuing debt with collateral. Thus, companies have an interest in issuing guaranteed debt. Other studies such as those of (Rajan and Zingales, 1995), (Berger et al., 1997),(Hovakimian et al., 2001), and (Frank and Goyal, 2003) found positive and significant relationships between guarantees and debt level. Nevertheless, (Köksal and Orman, 2015) concluded that tangibility is negatively associated with short-term debt but positively associated with long-term debt and total debt. Thus, companies with more tangible assets tend to have more long-term debt and less short-term in their capital structure. The fact that the signs of the estimated coefficients of the determinant of tangibility are opposite in the short-term and long-term debt equations has been interpreted by both authors as proof that companies in Turkey match the maturity of their assets with that of their liabilities.

3.2.3 Alternative Market Timing Measure $\left(\mathrm{MB}_{\text {eqwa,t }}\right)$

According to the $\mathrm{MB}_{\text {efwa }}$ weighting system, the issue of shares is the main means of external financing given the possibility of market timing. However, this supposition is not always admissible. To work around this, we will use a current total equity funding ratio over the study period. The alternative measure of market timing is defined as follows:

$$
\mathrm{MB}_{\text {eqwa, }}=\sum_{S=0}^{t-1} \frac{e_{S}}{\sum_{r=0}^{t-1} e_{r}} *\left(\frac{M}{B}\right)
$$

Where "e" represents the net issuance of debt summations are calculated from the IPO year to the year t-1 to avoid collinearity. The time index s and $r$ go from the IPO year to $t-1$.

\subsubsection{Impact of IPOs on Leverage}

According to the theory of market timing, companies don't adjust the market timing effect on their leverage. To confirm this assumption, we must identify a market timing event and study its ulterior impacts. The IPO may well be the best behavior in market timing. Several searches found that exit through an initial public offering is often considered the most preferred exit route from a buyout investment and that managers use market timing during the introduction. We know that issuing securities at the IPO reduces the leverage of a company. The question is whether 
the effect of market timing will be quickly rebalanced by the company in the following years. in accordance with the theory of static arbitrage, the company's current debt would never be affected by previous share issues. On the other hand, the theory of market timing confirms that their effect is persistent. Thereby, to distinguish these competing theories, we test the equity issuance effect on current debt. The model to regress is as follows:

$$
\mathrm{L}_{\mathrm{i}, \mathrm{t}}=\alpha_{0}+\sum_{j=1}^{T} \alpha_{1, j} e_{i, I P O} * \mathrm{yr}_{\mathrm{t}}+\alpha_{2}\left(\frac{M}{B}\right)_{\mathrm{i}, \mathrm{t}-1}+\alpha_{3}\left(\frac{E B I T D A}{A}\right)_{\mathrm{i}, \mathrm{t}-1}+\alpha_{4} \log (\mathrm{S})_{\mathrm{i}, \mathrm{t}-1}+\alpha_{5}\left(\frac{P P E}{B A}\right)_{\mathrm{i}, \mathrm{t}-1}+\mathrm{yr}_{\mathrm{t}}+\mathrm{v}_{\mathrm{i}}+\varepsilon_{\mathrm{i}, \mathrm{t}}
$$

$\mathrm{e}_{\mathrm{i}, \mathrm{IPO}}$ is net share issue in the initial public offering year by company $\mathrm{i}, \mathrm{yr}_{\mathrm{t}}$ is the dummy variable of the year, and $\sum_{j=1}^{T} \alpha_{1, j} \boldsymbol{e}_{i, I P o}$ is the sum of the interaction terms between the net issue of shares during the initial public offering year and the dummies of $j$ years after the initial public offering.

Direct impact of the issue of IPO securities on the company's current capital structure is captured by the coefficient $\alpha_{1, j}$, j years after the issue. It should be negligible in the years following the IPO, if companies quickly adjust the impact of capital injection. The importance of this test is that it is able to isolate the IPO effect from other attempts of market timing. The persistent significance of the coefficient indicates that the effect of previous share issues cannot be quickly rebalanced by companies

\subsubsection{Cumulative Adjustment Speed}

To test the possibility of adjustment, we regress a cumulative adjustment model to estimate the cumulative adjustment speed. This model estimates the extent to which the variations in the debt ratio in comparison to the IPO year are explained by the variation in the target debt ratio compared with the initial public offering year.

$$
L_{i, t}-L_{i, I P O}=\alpha\left(L_{i, t}^{*}-L_{i, I P O}\right)
$$

$L_{i, t}$ is the debt ratio of company i to year $\mathrm{t} ; L_{i, I P O}$ is the debt ratio of company $\mathrm{i}$ in the initial public offering year, $L_{i, t}^{*}$ is the target debt ratio of company $i$ to year $\mathrm{t}$, and $\alpha$ measures the cumulative adjustment speed from the initial public offering year. This shows how quickly a company closes the gap between the target debt ratio and the debt ratio during the initial public offering year. $0<\alpha<1$ indicates partial adjustment, $\alpha=0$ means that no adjustment is made, and $\alpha=1$ indicates a complete adjustment.

The reduced cumulative adjustment model is then

$$
L_{i, t}=(1-\alpha) L_{i, I P O}+\alpha L_{i, t}^{*}
$$

The target debt ratio is not observable. So, the used proxy is a prediction based on the characteristics of the start of the period. It is defined as follows:

$$
L_{i, t}^{*}=\gamma+\beta X_{i, t-1}+\left(\eta_{t}+v_{i, t}\right)
$$

Where $X_{i, t-1}$ is a vector of firm debt ratio determinants of company i to year t-1, including Market-to-Book ratio, EBITDA/total Assets, $\log$ (Sales), and PPE/Total assets. $\eta_{t}$ is the effect of the time series, and $v_{i, t}$ is the error term. The values obtained are used as a proxy for the target debt ratio.

\section{Analysis of Results}

\subsection{Capital Structure and Market Timing}

According to the literature, offerings, whether IPOs or SEOs, coincide with market overvaluation. These issues experience long-term market underperformance, considered as a proof of market timing. We tested the effect of the market-to-book ratio on the number of shares issued. This estimate allowed us to test whether companies raise more equity to take advantage of the relatively lower costs of issuing shares via market overvaluation. Then to solve the problem of the variation of market values across industries, we replaced the $M / B$ ratio with a $M / B$ ratio relative to the median $\mathrm{M} / \mathrm{B}$ industry ratio (RelM/B). RelM/B measures the change in the $\mathrm{M} / \mathrm{B}$ ratio of the company compared with its industry peers. A higher value for RelM/B indicates a higher market value for the business. To control the time effect, we created seven binary variables $I_{k}$, with $\mathrm{k}$ as the number of years following the IPO. $I_{k}$ takes the value 1 if the company has survived k years after the IPO (otherwise 0). Finally, to control the industry effect, we created eight binary variables $S_{n}$, which represent the eight sectors studied. $S_{n}$ takes the value 1 if the company belongs to the sector represented by the variable (otherwise 0 ). 
Table 2. Market value and equity issue

\begin{tabular}{|c|c|c|c|c|c|c|}
\hline & RLBOs & & & IPOs & & \\
\hline & Panel A & & & & & \\
\hline \multirow[t]{2}{*}{$\mathrm{M} / \mathrm{B}_{\mathrm{t}}$} & $4.10 * * *$ & $4.62 * * *$ & $4.35^{* * *}$ & $3.72 * * *$ & $3.72 * * *$ & $3.68 * * *$ \\
\hline & $(3.72)$ & $(4.76)$ & $(4.46)$ & $(10.34)$ & $(10.27)$ & $(10.06)$ \\
\hline Year Dummies & $\mathrm{N}$ & $\mathrm{Y}$ & $\mathrm{Y}$ & $\mathrm{N}$ & $\mathrm{Y}$ & $\mathrm{Y}$ \\
\hline Industry dummies & $\mathrm{N}$ & $\mathrm{N}$ & $\mathrm{Y}$ & $\mathrm{N}$ & $\mathrm{N}$ & $\mathrm{Y}$ \\
\hline $\mathrm{N}$ & 1224 & 1224 & 1224 & 1580 & 1580 & 1580 \\
\hline $\mathrm{R}$ & 0.01 & 0.24 & 0.25 & 0.06 & 0.08 & 0.09 \\
\hline F-Statistic & 13.82 & 34.93 & 21.39 & 107.02 & & \\
\hline \multirow[t]{2}{*}{ P-Value (F-Statistic) } & 0.0002 & 0.0000 & 0.0000 & & & \\
\hline & Panel B & & & & & \\
\hline \multirow[t]{2}{*}{ RelM/Bt } & $6.65^{* * *}$ & $7.23 * * *$ & $6.71 * * *$ & $8.64 * * *$ & $8.66^{* * *}$ & $8.63 * * *$ \\
\hline & $(3.42)$ & $(4.22)$ & $(3.89)$ & $(9.45)$ & $(9.41)$ & $(9.3)$ \\
\hline Year Dummies & $\mathrm{N}$ & $\mathrm{Y}$ & $\mathrm{Y}$ & $\mathrm{N}$ & $\mathrm{Y}$ & $\mathrm{Y}$ \\
\hline Industry dummies & $\mathrm{N}$ & $\mathrm{N}$ & $\mathrm{Y}$ & $\mathrm{N}$ & $\mathrm{N}$ & $\mathrm{Y}$ \\
\hline $\mathrm{N}$ & 1224 & 1224 & 1224 & 1580 & 1580 & 1580 \\
\hline $\mathrm{R}$ & 0.01 & 0.24 & 0.25 & 0.05 & 0.07 & 0.08 \\
\hline F-Statistic & 11.71 & 34.41 & 21.07 & & & \\
\hline P-Value (F-Statistic) & 0.0006 & 0.0000 & 0.0000 & & & \\
\hline
\end{tabular}

Note: Annual net equity issues is the dependent variable. The independent variable in panel A is Market-to-book ratio and in panel B is (RelM/B) ratio. The estimates of constant are not reported. t-statistics is in parentheses. *; **; *** indicates statistical significance at 1,5 and $10 \%$

Table II presents the results of the regression of the net share issue on the $\mathrm{M} / \mathrm{B}$ ratio in the panel. The relationship between the net share issue and the M/B ratio is positive and statistically significant for RLBOs as well as public companies. Indeed, the coefficient of the M/B ratio is positive and statistically significant at the threshold of $1 \%$. This implies that companies issue more shares as their $\mathrm{M} / \mathrm{B}$ ratios increase. This positive and significant relationship holds after controlling for the effects of time and industry.

Table II also presents the results of the regression of the net share issue on (RelM/B) ratio. The results obtained confirm those obtained in Panel A. Indeed, the relationship between the net emission of action and the RelM/B ratio is positive and statistically significant. The RelM/B ratio coefficient is positive and statistically significant at the $1 \%$ threshold even after controlling for the time and industry effects. This means that the net share issue increases with the rise of the M/B ratio of the company compared with its industry peers, whether for RLBOs or public companies. The positive relationship between the net issue and market value of the shares confirms the practice of market timing. Our results are consistent with those obtained by (Chen and Zhao, 2006), who provided evidence that companies with higher $\mathrm{M} / \mathrm{B}$ ratios are more motivated to issue shares because of the drop in external financing costs.

\subsection{The Market Timing Effect on Leverage}

The impact of the determinants of the capital structure of RLBOs and public companies on leverage obtained in our study is consistent with the results obtained by previous research. Indeed, according to the table III and table IV, the $\mathrm{M} / \mathrm{B}$ ratio has a negative effect on the capital structure throughout the period of our study, which is in accordance with (Myers, 1977) underinvestment theory. A high M/B ratio indicates that the firm has a lot of investment opportunities compared with its assets in place, which negatively affects its recourse to debt.

The negative coefficient associated with the operational performance of the company measured by the ratio EBITDA/total assets is consistent with the assumption that the most profitable companies have more internal 
resources and therefore use less debt. The company size, measured by $\log (\mathrm{S})$, is positively correlated with debt since large companies have large debt capacities. The positive coefficient associated with the tangibility of assets is consistent with the hypothesis according to which the more companies hold tangible assets, the more they incur debt because tangible fixed assets serve as collateral.

We obtained a difference between the impact of $\left(\mathrm{MB}_{\text {efwa }}\right)$ on the capital structure RLBOs and public enterprises. $\mathrm{MB}_{\text {efwa }}$ has a significantly negative effect on the capital structure of the two types of companies. The significance of the impact of market timing on the capital structure of public companies up to ten years after the IPO. However, we did not find the same result in the case of RLBOs. Indeed, the coefficient associated with $\mathrm{MB}_{\text {efwa }}$ is significant only during the second year and the third year following the IPO of RLBOs when it comes to the regression of the market leverage and only during the third year following one introduction during the regression of the book leverage. The $\mathrm{MB}_{\text {efwa }}$ coefficients are always negative, even if they are not significant. The results of the RLBOs are in line with the assumption of the theory of trade-off that companies should quickly adjust the impact of previous share issues so that market timing has no lasting effects on the capital structure.

Table 3. The impact of $\mathrm{MB}_{\text {efwa }}$ on market leverage: RLBOs VS. IPOs

\begin{tabular}{|c|c|c|c|c|c|c|c|c|c|c|}
\hline \multicolumn{11}{|l|}{ RLBOs } \\
\hline & $\mathrm{IPO}+1$ & $\mathrm{IPO}+2$ & $\mathrm{IPO}+3$ & $\mathrm{IPO}+4$ & $\mathrm{IPO}+5$ & IPO+6 & $\mathrm{IPO}+7$ & $\mathrm{IPO}+8$ & IPO+9 & $\mathrm{IPO}+10$ \\
\hline \multirow[t]{2}{*}{$\mathrm{M} / \mathrm{B}_{\text {efiva }}$} & -1.225 & $-0.632 * * *$ & $-0.673^{* * * *}$ & -0.776 & -0.765 & -0.864 & -0.847 & -0.870 & -1.073 & -0.978 \\
\hline & $(0.812)$ & $(0.159)$ & $(0.159)$ & $(0.768)$ & $(0.804)$ & $(0.895)$ & $(2.369)$ & $(2.426)$ & $(2.565)$ & $(1.190)$ \\
\hline \multirow[t]{2}{*}{$\mathrm{M} / \mathrm{B}$} & $-5.314^{* * *}$ & $-2.868 * * *$ & $-3.041 * * *$ & $-3.617^{* * *}$ & $-3.623 * * *$ & $-3.737 * * *$ & $-3.771 * * *$ & $-3.774 * * *$ & $-3.751 * * *$ & $-3.828 * * *$ \\
\hline & (1.789) & $(0.846)$ & $(0.836)$ & $(0.874)$ & $(0.900)$ & $(0.935)$ & $(0.885)$ & $(0.905)$ & $(0.952)$ & (1.103) \\
\hline \multirow[t]{2}{*}{ EBITDA/A } & $-0.566^{* * *}$ & $-0.345^{* * *}$ & $-0.376^{* * *}$ & $-0.501 * * *$ & $-0.488^{* * *}$ & $-0.467 * * *$ & $-0.501^{* * *}$ & $-0.498^{* * *}$ & $-0.497 * * *$ & $-0.477^{* * *}$ \\
\hline & $(0.158)$ & $(0.0680)$ & $(0.0666)$ & $(0.0626)$ & $(0.0681)$ & $(0.0755)$ & $(0.0794)$ & $(0.0819)$ & $(0.0872)$ & $(0.105)$ \\
\hline \multirow[t]{2}{*}{$\log (S)$} & $6.925 * * *$ & $3.265^{* *}$ & $2.763 * *$ & $2.789 * *$ & $2.560^{*}$ & $2.793^{*}$ & $3.520 * *$ & $3.369 * *$ & $3.277^{*}$ & 0.623 \\
\hline & $(2.560)$ & $(1.379)$ & (1.385) & (1.197) & $(1.314)$ & $(1.461)$ & $(1.554)$ & $(1.609)$ & $(1.771)$ & $(2.102)$ \\
\hline \multirow[t]{2}{*}{ PPE/A } & $0.457^{*}$ & $0.323 * * *$ & $0.233 * *$ & $0.0984 * * *$ & $0.0985 * * *$ & $0.102^{* * *}$ & $0.418^{* * *}$ & $0.416^{* * *}$ & $0.411^{* * *}$ & $0.408 * * *$ \\
\hline & $(0.232)$ & $(0.0901)$ & $(0.0915)$ & $(0.0226)$ & $(0.0234)$ & $(0.0242)$ & $(0.0922)$ & $(0.0944)$ & $(0.0994)$ & $(0.102)$ \\
\hline \multirow[t]{2}{*}{ Constant } & -0.341 & -0.253 & -0.187 & -0.253 & -0.214 & -0.236 & -0.325 & -0.306 & -0.300 & 0.112 \\
\hline & $(0.278)$ & $(0.185)$ & $(0.184)$ & $(0.165)$ & $(0.179)$ & $(0.198)$ & $(0.209)$ & $(0.217)$ & $(0.237)$ & $(0.291)$ \\
\hline Observations & 200 & 163 & 149 & 140 & 125 & 110 & 92 & 88 & 79 & 58 \\
\hline R-squared & 0.121 & 0.275 & 0.301 & 0.422 & 0.411 & 0.401 & 0.474 & 0.467 & 0.462 & 0.473 \\
\hline F-Statistic & 5.33 & 11.92 & 12.32 & 19.58 & 16.62 & 13.92 & 15.50 & 14.35 & 12.53 & 9.33 \\
\hline P-Value & 0.0001 & 0.0000 & 0.0000 & 0.0000 & 0.0000 & 0.0000 & 0.0000 & 0.0000 & 0.0000 & 0.0000 \\
\hline \multicolumn{11}{|l|}{ IPOs } \\
\hline & $\mathrm{IPO}+1$ & $\mathrm{IPO}+2$ & $\mathrm{IPO}+3$ & $\mathrm{IPO}+4$ & $\mathrm{IPO}+5$ & IPO+6 & $\mathrm{IPO}+7$ & $\mathrm{IPO}+8$ & $\mathrm{IPO}+9$ & $\mathrm{IPO}+10$ \\
\hline \multirow[t]{2}{*}{$\mathrm{M} / \mathrm{B}_{\text {efwa }}$} & $-1.632^{* *}$ & $-1.270 * * *$ & $-1.801^{* * * *}$ & $-1.768^{* * * *}$ & $-2.076^{* * *}$ & $-2.075 * * *$ & $-2.046^{* * *}$ & $-1.877^{* * *}$ & $-1.870^{* * *}$ & $-2.691 * * *$ \\
\hline & $(0.773)$ & $(0.479)$ & $(0.491)$ & $(0.523)$ & $(0.727)$ & $(0.615)$ & $(0.636)$ & $(0.583)$ & $(0.605)$ & $(0.882)$ \\
\hline \multirow[t]{2}{*}{$\mathrm{M} / \mathrm{B}$} & -1.351 & -1.783 & $-1.048^{* * * *}$ & $-1.022^{* * *}$ & $-1.182^{* * *}$ & $-1.185^{* * *}$ & $-1.191^{* * *}$ & $-1.032^{* * *}$ & $-1.027^{* * *}$ & $-1.517^{* * *}$ \\
\hline & $(4.504)$ & $(6.396)$ & $(0.336)$ & $(0.346)$ & $(0.389)$ & $(0.373)$ & $(0.386)$ & $(0.354)$ & $(0.367)$ & $(0.481)$ \\
\hline \multirow[t]{2}{*}{ EBITDA/A } & $-0.348 * *$ & $-0.301 * * *$ & $-0.600^{* * * *}$ & $-0.577^{* * *}$ & $-0.589 * * *$ & $-0.680 * * *$ & $-0.691 * * *$ & $-0.559 * * *$ & $-0.554^{* * *}$ & $-0.705^{* * *}$ \\
\hline & $(0.154)$ & $(0.0764)$ & $(0.0717)$ & $(0.0716)$ & $(0.0862)$ & $(0.0752)$ & $(0.0801)$ & $(0.0761)$ & $(0.0799)$ & $(0.101)$ \\
\hline \multirow[t]{2}{*}{$\log (\mathrm{S})$} & $2.193^{* * *}$ & $3.778^{* * *}$ & $4.556^{* * *}$ & $4.172^{* *}$ & $2.883^{* * *}$ & $3.489 * * *$ & $3.111^{* * *}$ & $3.738 * * *$ & $3.695^{* * *}$ & $3.761 * * *$ \\
\hline & $(0.828)$ & $(0.857)$ & $(1.735)$ & $(1.708)$ & $(1.201)$ & $(0.872)$ & $(0.926)$ & (1.304) & $(1.371)$ & $(1.345)$ \\
\hline \multirow[t]{2}{*}{$\mathrm{PPE} / \mathrm{A}$} & 0.101 & $0.310^{*}$ & $0.500 * * *$ & $0.479 * * *$ & $0.459^{* *}$ & $0.614^{* * *}$ & $0.674 * * *$ & $0.656^{* * *}$ & $0.678^{* * *}$ & $0.401 * *$ \\
\hline & $(0.0946)$ & $(0.160)$ & $(0.163)$ & $(0.167)$ & $(0.210)$ & $(0.182)$ & $(0.199)$ & $(0.191)$ & $(0.203)$ & $(0.194)$ \\
\hline \multirow[t]{2}{*}{ Constant } & 0.0780 & $-1.404^{* *}$ & $-0.125^{*}$ & $-0.115^{*}$ & $-0.151^{* *}$ & $-0.204^{* * *}$ & $-0.171^{* *}$ & $-0.145^{* *}$ & $-0.144^{* *}$ & $-0.193 * *$ \\
\hline & $(0.0710)$ & $(0.634)$ & $(0.0651)$ & $(0.0642)$ & $(0.0732)$ & $(0.0639)$ & $(0.0689)$ & $(0.0639)$ & $(0.0671)$ & $(0.0823)$ \\
\hline Observations & 198 & 191 & 176 & 174 & 160 & 153 & 142 & 132 & 122 & 108 \\
\hline R-squared & 0.101 & 0.154 & 0.339 & 0.319 & 0.264 & 0.390 & 0.391 & 0.350 & 0.347 & 0.371 \\
\hline F-Statistic & 4.32 & 6.73 & 17.46 & 15.71 & 11.04 & 18.78 & 17.44 & 13.60 & 12.32 & 12.05 \\
\hline P-Value & 0.0009 & 0.0000 & 0.0000 & 0.0000 & 0.0000 & 0.0000 & 0.0000 & 0.0000 & 0.0000 & 0.0000 \\
\hline
\end{tabular}

Note: Regression results of market leverage on $\left(\mathrm{MB}_{\text {efwa }}\right)$ and firm characteristics. *; **; *** indicates statistical significance at 1,5 and 10\%. Standard errors are in parentheses 
Table 4. The impact of $\mathrm{MB}_{\text {efwa }}$ on book leverage: RLBOs VS. IPOs

\begin{tabular}{|c|c|c|c|c|c|c|c|c|c|c|}
\hline \multicolumn{11}{|l|}{ RLBOs } \\
\hline VARIABLES & $\mathrm{IPO}+1$ & $\mathrm{IPO}+2$ & $\mathrm{IPO}+3$ & $\mathrm{IPO}+4$ & $\mathrm{IPO}+5$ & $\mathrm{IPO}+6$ & $\mathrm{IPO}+7$ & $\mathrm{IPO}+8$ & $\mathrm{IPO}+9$ & $\mathrm{IPO}+10$ \\
\hline \multirow[t]{2}{*}{$\mathrm{M} / \mathrm{B}_{\text {efwa }}$} & -5.805 & -1.232 & $-3.519 * * *$ & -2.617 & -4.304 & -3.855 & -3.908 & -3.612 & -3.118 & -9.698 \\
\hline & $(33.21)$ & $(22.12)$ & $(1.291)$ & $(2.396)$ & $(2.842)$ & $(2.937)$ & $(6.242)$ & $(6.331)$ & $(6.689)$ & $(7.432)$ \\
\hline \multirow[t]{2}{*}{$\mathrm{M} / \mathrm{B}$} & $-0.140^{* *}$ & $-0.145^{* *}$ & $-0.144^{* *}$ & $-0.307^{* *}$ & $-0.280^{*}$ & $-0.299 * *$ & $-0.305^{*}$ & $-0.313^{*}$ & $-0.325^{*}$ & $-0.334^{*}$ \\
\hline & $(0.0587)$ & $(0.0620)$ & $(0.0713)$ & $(0.136)$ & $(0.143)$ & $(0.149)$ & $(0.157)$ & $(0.160)$ & $(0.167)$ & $(0.185)$ \\
\hline \multirow[t]{2}{*}{ EBITDA/A } & $-3.068^{* * *}$ & $-2.174^{*}$ & $-2.541^{* * *}$ & $-1.092^{* * *}$ & $-1.106^{* * *}$ & $-1.072^{* * *}$ & $-1.524^{* *}$ & $-1.517^{* *}$ & $-1.491^{* *}$ & $-1.860^{* *}$ \\
\hline & (1.113) & $(1.254)$ & $(0.691)$ & $(0.211)$ & $(0.225)$ & $(0.227)$ & $(0.617)$ & $(0.627)$ & $(0.663)$ & $(0.731)$ \\
\hline \multirow[t]{2}{*}{$\log (\mathrm{S})$} & $4.612^{* *}$ & $4.009^{*}$ & $5.447^{* *}$ & $3.898^{* * *}$ & $3.747^{* * *}$ & $4.379 * * *$ & $4.784^{* *}$ & $4.294^{* *}$ & $4.689^{* *}$ & $6.553^{* *}$ \\
\hline & $(1.990)$ & $(2.257)$ & $(2.432)$ & (1.418) & $(1.548)$ & $(1.617)$ & (1.847) & $(1.922)$ & $(2.061)$ & $(2.504)$ \\
\hline \multirow[t]{2}{*}{ PPE/A } & $1.000^{* * *}$ & $0.880^{*}$ & $1.038^{* *}$ & $0.939 * *$ & $0.913^{*}$ & $1.277^{* *}$ & $1.020^{*}$ & $1.034^{*}$ & $1.174^{*}$ & $2.058^{* *}$ \\
\hline & $(0.310)$ & $(0.479)$ & $(0.481)$ & $(0.468)$ & $(0.517)$ & $(0.542)$ & $(0.586)$ & $(0.597)$ & $(0.650)$ & $(0.784)$ \\
\hline \multirow[t]{2}{*}{ Constant } & -0.0581 & -0.00528 & -0.0414 & -0.0599 & -0.0405 & -0.148 & -0.143 & -0.0940 & -0.142 & -0.465 \\
\hline & $(0.115)$ & $(0.144)$ & $(0.151)$ & $(0.166)$ & $(0.181)$ & $(0.191)$ & $(0.222)$ & $(0.232)$ & $(0.249)$ & $(0.310)$ \\
\hline Observations & 200 & 163 & 149 & 140 & 125 & 110 & 92 & 88 & 79 & 58 \\
\hline$R$-squared & 0.122 & 0.083 & 0.182 & 0.224 & 0.228 & 0.253 & 0.232 & 0.229 & 0.239 & 0.302 \\
\hline F-Statistic & 5.38 & 2.83 & 6.37 & 7.75 & 7.04 & 7.05 & 5.19 & 4.86 & 4.59 & 4.51 \\
\hline P-Value & 0.0001 & 0.0178 & 0.0000 & 0.0000 & 0.0000 & 0.0000 & 0.0003 & 0.0006 & 0.0011 & 0.0017 \\
\hline \multicolumn{11}{|l|}{ IPOs } \\
\hline VARIABLES & $\mathrm{IPO}+1$ & $\mathrm{IPO}+2$ & $\mathrm{IPO}+3$ & $\mathrm{IPO}+4$ & $\mathrm{IPO}+5$ & $\mathrm{IPO}+6$ & $\mathrm{IPO}+7$ & $\mathrm{IPO}+8$ & $\mathrm{IPO}+9$ & $\mathrm{IPO}+10$ \\
\hline \multirow[t]{2}{*}{$\mathrm{M} / \mathrm{B}_{\text {efwa }}$} & $-2.919 * * *$ & $-2.516^{* *}$ & $-2.416^{*}$ & $-2.308^{*}$ & $-2.662^{* *}$ & $-5.805 * * *$ & $-5.969 * * *$ & $-6.553^{* * *}$ & $-6.659 * * *$ & $-4.305^{* *}$ \\
\hline & (1.071) & (1.158) & $(1.252)$ & $(1.275)$ & (1.299) & (1.448) & (1.549) & $(1.606)$ & (1.744) & (1.653) \\
\hline \multirow[t]{2}{*}{$\mathrm{M} / \mathrm{B}$} & $-1.327^{* *}$ & $-1.367^{* *}$ & $-1.370^{* *}$ & $-1.476^{* *}$ & -0.939 & $-1.884^{* * *}$ & $-1.681^{* * *}$ & $-1.471^{* *}$ & $-1.429 * *$ & $-1.727^{* * * *}$ \\
\hline & $(0.536)$ & $(0.555)$ & $(0.576)$ & $(0.575)$ & $(0.717)$ & $(0.559)$ & $(0.573)$ & $(0.594)$ & $(0.605)$ & $(0.565)$ \\
\hline \multirow[t]{2}{*}{ EBITDA/A } & $-0.515^{* *}$ & $-0.404^{*}$ & $-0.416^{*}$ & $-0.396^{*}$ & $-0.550^{* *}$ & $-0.178^{* *}$ & $-0.166^{* * *}$ & $-0.162^{*}$ & $-0.155^{*}$ & $-0.216^{* * *}$ \\
\hline & $(0.209)$ & $(0.216)$ & $(0.224)$ & $(0.225)$ & $(0.229)$ & $(0.0826)$ & $(0.0835)$ & $(0.0846)$ & $(0.0861)$ & $(0.0723)$ \\
\hline \multirow[t]{2}{*}{ Log $(S)$} & $4.568^{* * *}$ & $4.423^{* * *}$ & $4.196 * * *$ & $4.082^{* * *}$ & $3.904^{* * *}$ & $5.743^{* * *}$ & $5.477^{* * *}$ & $5.184^{* * * *}$ & $4.977^{* * *}$ & $5.765^{* * *}$ \\
\hline & $(0.490)$ & $(0.533)$ & $(0.584)$ & $(0.599)$ & $(0.610)$ & $(0.939)$ & $(0.957)$ & $(0.982)$ & (1.011) & $(0.989)$ \\
\hline \multirow[t]{2}{*}{ PPE/A } & $0.160^{*}$ & $0.188^{*}$ & $0.189^{*}$ & $0.207 * *$ & $0.211^{* *}$ & $0.173^{*}$ & $0.231 * *$ & $0.205^{*}$ & $0.269 * *$ & $0.183^{*}$ \\
\hline & $(0.0965)$ & $(0.0976)$ & $(0.103)$ & $(0.103)$ & $(0.106)$ & $(0.102)$ & $(0.108)$ & $(0.114)$ & $(0.125)$ & $(0.109)$ \\
\hline \multirow[t]{2}{*}{ Constant } & $-0.326^{* * * *}$ & $-0.302^{* * *}$ & $-0.272^{* * *}$ & $-0.261^{* * * *}$ & $-0.243^{* *}$ & $-0.190^{*}$ & $-0.172^{*}$ & -0.144 & -0.133 & -0.0381 \\
\hline & $(0.0832)$ & $(0.0879)$ & $(0.0938)$ & $(0.0956)$ & $(0.0967)$ & $(0.0993)$ & $(0.101)$ & $(0.103)$ & $(0.105)$ & $(0.111)$ \\
\hline Observations & 198 & 191 & 176 & 174 & 160 & 153 & 142 & 132 & 122 & 108 \\
\hline$R$-squared & 0.411 & 0.366 & 0.328 & 0.316 & 0.321 & 0.365 & 0.364 & 0.351 & 0.356 & 0.403 \\
\hline F-Statistic & 26.83 & 21.35 & 16.59 & 15.50 & 14.53 & 16.90 & 15.60 & 13.61 & 12.81 & 13.78 \\
\hline P-Value & 0.0000 & 0.0000 & 0.0000 & 0.0000 & 0.0000 & 0.0000 & 0.0000 & 0.0000 & 0.0000 & 0.0000 \\
\hline
\end{tabular}

Note: Regression results of book leverage on $\left(\mathrm{MB}_{\text {efwa }}\right)$ and firm characteristics. *; **; *** indicates statistical significance at 1,5 and $10 \%$. Standard errors are in parentheses

\subsection{Alternative Market Timing Measure}

Table $\mathrm{V}$ shows the results of the regression of the book leverage on the alternative measure of market timing $\mathrm{MB}_{\text {eqwa }}$ and the four main determinants of the capital structure.

The regression results confirm previous results. The M/B ratio has a negative effect on the capital structure. The profitability measured by the ratio EBITDA/total assets negatively affects the company's level of indebtedness. The company size measured by $\log (\mathrm{S})$ is positively correlated with debt. The tangibility of the assets measured by the ratio PPE/total assets is also positively linked to debt. The significance of the determinants persisted during the ten years of the study in the case of the two types of business.

In accordance with previous results, the impact of the alternative measure of market timing $\left(\mathrm{MB}_{\text {eqwa }}\right)$ on the capital structure is different between RLBOs and public companies. Nevertheless, $\mathrm{MB}_{\text {eqwa }}$ has a significantly negative effect on the capital structure of both types of companies. The impact of market timing on the capital structure of public companies is statistically significant throughout the ten years of our study. However, the market timing effect on the capital structure of RLBOs is not sustainable. This result is consistent with the prediction of the trade-off theory.

The non-persistence of the effect of market timing on the capital structure of companies is not limited to the case of European RLBOs. Rather, it has been confirmed by several previous studies. (Kayhan and Titman, 2007) confirmed that the change in debt is consistent with the market timing theory, but unlike (Baker and Wurgler, 2002), they did not find a persistent effect on the capital structure. In a review of Dutch companies by (Bie and de Haan, 2007), the existence of market timing was proven but without the prolonged persistence of its effect on the capital structure of 
Dutch companies. (Mahajan and Tartaroglu, 2008) found that in all G7 countries, corporate debt is negatively correlated with the historical value of the $\mathrm{M} / \mathrm{B}$ ratio, which corresponds to the market timing theory. However, they have not proven the lasting effect of market timing on the capital structure.

Table 5. Market timing' impact on leverage using alternative measure $\left(\mathrm{MB}_{\text {eqwa,t }}\right)$

\begin{tabular}{|c|c|c|c|c|c|c|c|c|c|c|}
\hline \multicolumn{11}{|l|}{ RLBOs } \\
\hline & $\mathrm{IPO}+1$ & $\mathrm{IPO}+2$ & $\mathrm{IPO}+3$ & IPO +4 & $\mathrm{IPO}+5$ & $\mathrm{IPO}+6$ & $\mathrm{IPO}+7$ & $\mathrm{IPO}+8$ & $\mathrm{IPO}+9$ & $\mathrm{IPO}+10$ \\
\hline \multirow[t]{2}{*}{ M/Banses } & $-1.253 * *$ & $-3.694 * * *$ & $-3.505 * * *$ & -1.823 & -1.396 & -2.021 & -2.915 & -4.129 & -2.849 & -1.218 \\
\hline & $(0.573)$ & $(0.995)$ & $(1.025)$ & $(1.372)$ & $(1.471)$ & $(1.660)$ & $(2.003)$ & $(2.907)$ & $(3.091)$ & (12.94) \\
\hline \multirow{2}{*}{$\mathrm{M} / \mathrm{B}$} & $-1.618^{* *}$ & $-6.765^{* * *}$ & $-6.414 * * *$ & $-3.094^{* * *}$ & $-3.595^{* * *}$ & $-3.446^{* * *}$ & $-3.468 * * *$ & $-3.646^{* * *}$ & $-3.537 * * *$ & $-3.409 * * *$ \\
\hline & $(0.758)$ & $(2.108)$ & $(2.171)$ & $(0.995)$ & $(1.076)$ & (1.153) & $(1.274)$ & $(0.938)$ & $(0.999)$ & $(1.245)$ \\
\hline \multirow[t]{2}{*}{ EBITDA/A } & $-0.333^{* *}$ & $-0.315^{* * *}$ & $-0.314 * * *$ & $-0.413^{* * *}$ & $-0.421^{* * *}$ & $-0.429 * * *$ & $-0.433^{* * *}$ & $-0.155^{* * *}$ & $-0.152^{* *}$ & $-0.165^{* *}$ \\
\hline & $(0148)$ & $(0.0337)$ & $(0.0359)$ & $(0.0630)$ & $(0.0657)$ & $(0.0718)$ & $(0.0805)$ & $(0.0550)$ & $(0.0583)$ & $(0.0720)$ \\
\hline \multirow{2}{*}{$\log (S)$} & $1.514^{*}$ & $3.528 * * *$ & $3.436 * * *$ & $2.167 * * *$ & $2.232 * * *$ & $2.310^{* * *}$ & $2.449^{* * * *}$ & $1.211^{*} *$ & $1.130 * *$ & $1.162^{*}$ \\
\hline & $(0.804)$ & $(0.860)$ & $(0.913)$ & $(0.652)$ & $(0.676)$ & $(0.711)$ & $(0.769)$ & $(0.505)$ & $(0.536)$ & $(0.663)$ \\
\hline \multirow[t]{2}{*}{$\mathrm{PPE} / \mathrm{A}$} & 0.117 & $0.545^{* * *}$ & $0.498 * * *$ & $0.538^{* * * *}$ & $0.542^{* * * *}$ & $0.578^{* * *}$ & $0.614 * * *$ & $0.875^{* * *}$ & $0.895 * * *$ & $0.930 * * *$ \\
\hline & $(0.0946)$ & $(0.169)$ & $(0.182)$ & $(0.101)$ & $(0.107)$ & $(0.114)$ & $(0.125)$ & $(0.0713)$ & $(0.0755)$ & $(0.101)$ \\
\hline \multirow[t]{2}{*}{ Constant } & 0.0473 & $-1.466^{* * *}$ & $-1.398 * * *$ & 0.0559 & 0.0752 & 0.0183 & -0.0435 & -0.0522 & -0.0571 & 0.0137 \\
\hline & $(0.0731)$ & $(0.289)$ & $(0.310)$ & $(0.102)$ & $(0.107)$ & $(0.116)$ & $(0.129)$ & $(0.360)$ & $(0.383)$ & $(0.479)$ \\
\hline \multirow{2}{*}{$\begin{array}{l}\text { Observations } \\
R \text {-squared }\end{array}$} & 210 & 170 & 152 & 140 & 125 & 110 & 92 & 88 & 79 & 58 \\
\hline & 0.117 & 0.399 & 0.381 & 0.441 & 0.464 & 0.476 & 0.490 & 0.787 & 0.792 & 0.717 \\
\hline \multirow{2}{*}{$\begin{array}{l}\text { F-Statistic } \\
\text { P-Value }\end{array}$} & 5.38 & 21.77 & 18.01 & 21.17 & 20.60 & 18.89 & 16.53 & 26.70 & 25.51 & 26.32 \\
\hline & 0.0001 & 0.0000 & 0.0000 & 0.0000 & 0.0000 & 0.0000 & 0.000 & 0.000 & 0.0000 & 0.0000 \\
\hline \multicolumn{11}{|l|}{ IPOs } \\
\hline & $\mathrm{IPO}+1$ & $\mathrm{IPO}+2$ & $\mathrm{IPO}+3$ & $\mathrm{IPO}+4$ & $\mathrm{IPO}+5$ & $\mathrm{IPO}+6$ & $\mathrm{IPO}+7$ & $\mathrm{IPO}+8$ & $\mathrm{IPO}+9$ & $\mathrm{IPO}+10$ \\
\hline \multirow[t]{2}{*}{$\mathrm{M} / \mathrm{B}_{\text {eavea }}$} & $-3.311^{* * *}$ & $-3.688^{* * * *}$ & $-3.248 * * *$ & $-3.416^{* * * *}$ & $-2.436^{* *}$ & $-2.494 * *$ & $-2.506^{* *}$ & $-2.550 * *$ & $-2.561 * *$ & $-3.220 * * *$ \\
\hline & $(1.002)$ & $(1.021)$ & $(0.974)$ & $(0.969)$ & $(1.014)$ & $(1.031)$ & $(1.059)$ & $(1.079)$ & $(1.116)$ & $(0.992)$ \\
\hline \multirow[t]{2}{*}{$\mathrm{M} / \mathrm{B}$} & $-6.518^{* * *}$ & $-3.460 * * *$ & $-2.927 * * *$ & $-3.082 * * *$ & $-2.489 * *$ & $-2.574^{* *}$ & $-2.579^{* *}$ & $-2.654^{* *}$ & $-2.676^{* *}$ & $-2.848 * * *$ \\
\hline & $(2.134)$ & $(1.084)$ & $(1.033)$ & $(1.029)$ & $(1.081)$ & $(1.097)$ & $(1.126)$ & $(1.148)$ & $(1.187)$ & $(1.043)$ \\
\hline \multirow[t]{2}{*}{ EBITDA/A } & $-0.328^{* * *}$ & $-0.172^{* * *}$ & $-0.141 * * *$ & $-0.152^{* * *}$ & $-0.112^{* * * *}$ & $-0.120 * * *$ & $-0.121 * * *$ & $-0.116^{* * *}$ & $-0.114^{* * * *}$ & $-0.134^{* * * *}$ \\
\hline & $(0.0319)$ & $(0.0166)$ & $(0.0160)$ & $(0.0165)$ & $(0.0140)$ & $(0.0144)$ & $(0.0149)$ & $(0.0159)$ & $(0.0167)$ & $(0.0214)$ \\
\hline \multirow[t]{2}{*}{$\log (S)$} & $2.440 * * *$ & $2.775^{* * * *}$ & $2.148 * * *$ & $2.391^{* * *}$ & $4.481^{* *}$ & $4.051^{* *}$ & $4.520 * *$ & $3.573^{*}$ & $3.900^{*}$ & $3.856^{* *}$ \\
\hline & $(0.581)$ & $(0.605)$ & $(0.602)$ & $(0.608)$ & $(1.800)$ & $(1.921)$ & $(2.049)$ & (1.936) & $(2.075)$ & $(1.593)$ \\
\hline \multirow[t]{2}{*}{ PPE/A } & $0.499 * * *$ & $0.510 * * *$ & $0.408 * *$ & $0.445^{* * *}$ & $0.477^{*}$ & $0.549^{*}$ & $0.524^{*}$ & $0.581^{*}$ & $0.628 *$ & $0.471^{* *}$ \\
\hline & $(0.164)$ & $(0.169)$ & $(0.162)$ & $(0.165)$ & $(0.279)$ & $(0.282)$ & $(0.295)$ & $(0.306)$ & $(0.332)$ & $(0.200)$ \\
\hline \multirow[t]{2}{*}{ Constant } & $-1.283^{* * *}$ & $-1.445 * * *$ & $-1.174 * * *$ & $-1.286^{* * *}$ & $-0.209^{* * * *}$ & $-0.199 * * *$ & $-0.211 * * *$ & $-0.231 * * *$ & $-0.255^{* * * *}$ & $-1.157^{* * * *}$ \\
\hline & $(0.265)$ & $(0.275)$ & $(0.275)$ & $(0.277)$ & $(0.0699)$ & $(0.0700)$ & $(0.0747)$ & $(0.0747)$ & $(0.0795)$ & $(0.348)$ \\
\hline Observations & 210 & 191 & 180 & 174 & 165 & .153 & 145 & 132 & 122 & 108 \\
\hline$R$-squared & 0.370 & 0.397 & 0.343 & 0.371 & 0.328 & 0.361 & 0.358 & 0.339 & 0.333 & 0.355 \\
\hline F-Statistic & 23.96 & 24.33 & 18.17 & 19.81 & 15.50 & 16.62 & 15.49 & 12.90 & 11.59 & 11.21 \\
\hline P-Value & 0.0000 & 0.0000 & 0.0000 & 0.0000 & 0.0000 & 0.0000 & 0.0000 & 0.0000 & 0.0000 & 0.0000 \\
\hline
\end{tabular}

Note: Regression results of book leverage on $\left(\mathrm{MB}_{\text {eqwa }}\right)$ ratio and firm characteristics. *; **; *** indicates statistical significance at 1, 5 and $10 \%$. Standard errors are in parenthese

\subsection{Impact of Share Issuance During IPOs on Leverage}

Table 6. IPO equity issuance effect on leverage

\begin{tabular}{lllll}
\hline & Market Leverage & \multicolumn{3}{l}{ Book Leverage } \\
\hline VARIABLES & RLBOs & IPOs & RLBOs & IPOs \\
\hline $\mathrm{e}_{\mathrm{IPO}} * \mathrm{yr}_{1}$ & $-0.208^{* *}$ & $-0.118^{* * *}$ & $-0.134 * * *$ & $-0.0767 * *$ \\
\hline & $(0.0863)$ & $(0.0339)$ & $(0.0483)$ & $(0.0333)$ \\
\hline $\mathrm{e}_{\mathrm{IPO}} * \mathrm{yr}_{2}$ & $-0.122^{* * *}$ & $-0.0946^{*}$ & $-0.0548 * * *$ & $-0.0915^{* * *}$ \\
\hline & $(0.0390)$ & $(0.0517)$ & $(0.0162)$ & $(0.0326)$ \\
\hline $\mathrm{e}_{\mathrm{IPO}} * \mathrm{yr}_{3}$ & $-0.135^{* * *}$ & $-0.115^{* * *}$ & $-0.0647 * *$ & $-0.101^{* * *}$ \\
\hline & $(0.0350)$ & $(0.0115)$ & $(0.0254)$ & $(0.0111)$ \\
\hline $\mathrm{e}_{\mathrm{IPO}} * \mathrm{yr}_{4}$ & $-0.113^{* * *}$ & $-0.111^{* * *}$ & 0.0110 & $-0.137 * * *$ \\
\hline & $(0.0249)$ & $(0.0298)$ & $(0.0350)$ & $(0.0253)$ \\
\hline $\mathrm{e}_{\mathrm{IPO}} * \mathrm{yr}_{5}$ & -0.187 & $-0.162^{* * *}$ & -0.0699 & $-0.175^{* * *}$ \\
\hline $\mathrm{e}_{\mathrm{IPO}} * \mathrm{yr}_{6}$ & $(0.162)$ & $(0.0413)$ & $(0.0390)$ & $(0.0465)$ \\
\hline
\end{tabular}




\begin{tabular}{|c|c|c|c|c|}
\hline & $(0.0967)$ & $(0.0844)$ & $(0.434)$ & $(0.103)$ \\
\hline \multirow[t]{2}{*}{$\mathrm{e}_{\mathrm{IPO}} * \mathrm{yr}_{7}$} & -0.0322 & $-0.266^{* * *}$ & -0.0267 & $-0.288 * * *$ \\
\hline & $(0.0706)$ & $(0.0962)$ & $(0.0397)$ & $(0.0740)$ \\
\hline \multirow[t]{2}{*}{$\mathrm{e}_{\mathrm{IPO}} * \mathrm{yr}_{8}$} & 0.0944 & $-0.262 * * *$ & -0.0235 & $-0.297 * * *$ \\
\hline & $(0.190)$ & $(0.0824)$ & $(0.0244)$ & $(0.0952)$ \\
\hline \multirow[t]{2}{*}{$\mathrm{e}_{\mathrm{IPO}} * \mathrm{yr}_{9}$} & 0.0960 & $-0.0170 *$ & -0.0305 & $-0.194 * *$ \\
\hline & $(0.117)$ & $(0.00983)$ & $(0.0238)$ & $(0.0963)$ \\
\hline \multirow[t]{2}{*}{$\mathrm{e}_{\mathrm{IPO}} * \mathrm{yr}_{10}$} & 0.0345 & $-0.0701 * * *$ & -0.0432 & -0.0494 \\
\hline & $(0.134)$ & $(0.0214)$ & $(0.0649)$ & $(0.111)$ \\
\hline \multirow[t]{2}{*}{$\mathrm{M} / \mathrm{B}$} & $-4.443 * * *$ & $-1.843 * *$ & $-3.398 * * *$ & $-2.154 * * *$ \\
\hline & $(1.242)$ & $(0.715)$ & $(0.955)$ & $(0.650)$ \\
\hline \multirow[t]{2}{*}{ EBITDA/A } & $-3.120 * * *$ & $-0.256^{* * *}$ & $-0.167 * *$ & $-0.309 * * *$ \\
\hline & $(0.860)$ & $(0.0608)$ & $(0.0718)$ & $(0.0637)$ \\
\hline \multirow[t]{2}{*}{$\log (\mathrm{S})$} & $3.347 * * *$ & $4.576^{* * *}$ & $1.631 * * *$ & $5.419 * * *$ \\
\hline & $(1.060)$ & $(0.590)$ & $(0.592)$ & (0.656) \\
\hline \multirow[t]{2}{*}{ PPE/A } & $0.463 * *$ & $0.479 * * *$ & $0.132 * * *$ & $0.353 * * *$ \\
\hline & $(0.191)$ & $(0.0875)$ & $(0.0504)$ & $(0.0927)$ \\
\hline \multirow[t]{2}{*}{ Constant } & $-2.276^{* * *}$ & $-0.602 * * *$ & $0.167 * * *$ & $-0.276^{* * *}$ \\
\hline & $(0.0893)$ & $(0.0725)$ & $(0.0411)$ & $(0.0772)$ \\
\hline Observations & 1,224 & 1,574 & 1,224 & 1,580 \\
\hline R-squared & 0.075 & 0.222 & 0.071 & 0.203 \\
\hline F-Statistic & 10.22 & 24.62 & 11.06 & 32.55 \\
\hline P-Value & 0.0000 & 0.0000 & 0.0000 & 0.0000 \\
\hline Hausman test & 13.44 & 16.24 & 14.36 & 18.95 \\
\hline P-value & 0.0240 & 0.0147 & 0.0200 & 0.0103 \\
\hline Breusch-Pagan test & 0.381 & 0.831 & 0.312 & 1.047 \\
\hline P-value & 0.549 & 0.386 & 0.597 & 0.221 \\
\hline
\end{tabular}

Note: $\mathrm{e}_{\mathrm{i}, \mathrm{IPO}} \times \mathrm{yr}_{\mathrm{t}}$ is interactive terms between net equity issues at the IPO and the dummies for each year after IPO. *; $* * ; * *$ indicates statistical significance at 1, 5 and $10 \%$. Standard errors are in parentheses.

In accordance with the results of the previous section, results presented in table VI show that the issue of shares on the stock market affects the capital structure of the two types of companies differently.

The appropriate estimator used to compute regression coefficients was chosen based on the results of the Hausman test with the hypothesis H0: the random effects model (REM) is more appropriate. Thus, the Hausman test attests that the use of the fixed effects model (FEM) is more appropriate than the REM model. The heteroscedasticity test (Breusch-Pagan test) shows that all statistics are significantly higher than $5 \%$, indicating that there is no heteroscedasticity problem.

Concerning public companies, share issues during the IPO year have a significantly negative impact on debt. The issuance of shares at the time of the IPO persistently reduces the debt ratio. As time passes, the effect of share issues on the capital structure of public companies increases, reaching its peak in the eighth year following the IPO during the regression of the book leverage and the sixth year during the regression of the market leverage.

On the other hand, the share issues effect at the IPO is feeble and transient for RLBOs. However, the impact of issuance of shares during the IPO year on the debt of RLBOs is significantly negative. For the regression of the book 
leverage, the coefficients of the share issues are generally insignificant, and they are significant only until the third year following the IPO. For the regression of the market leverage, the coefficients of the share issues are not significantly negative until four years after the IPO. In addition, the level of significance is much lower than that of public companies.

The results of the RLBOs are more in line with the forecast of the theory of trade-off. Previous share issuance transactions do not have a durable impact on the capital structure of RLBOs since RLBOs adjust the effect of market timing on their capital structures much faster than their public counterparts.

\subsection{Cumulative Adjustment Speed}

According to our results, the market timing effect on the RLBOs' capital structure is more transient than its impact on the capital structure of public companies. Consequently, RLBOs immediately adjust the impact of previous financing decisions and thus move toward the debt ratio target more rapidly than public companies. So, RLBOs should have a faster adjustment speed.

Table 7. Cumulative speed of adjustment

\begin{tabular}{|c|c|c|c|c|c|c|c|c|c|c|}
\hline \multicolumn{11}{|l|}{ RLBOs } \\
\hline & $\mathrm{IPO}+1$ & $\mathrm{IPO}+2$ & $\mathrm{IPO}+3$ & $\mathrm{IPO}+4$ & $\mathrm{IPO}+5$ & $\mathrm{IPO}+6$ & $\mathrm{IPO}+7$ & $\mathrm{IPO}+8$ & $\mathrm{IPO}+9$ & $\mathrm{IPO}+10$ \\
\hline \multirow[t]{2}{*}{$\mathrm{L}_{\mathrm{IPO}}$} & $0.995^{*}$ *水* & $0.704^{*} * *$ & $0.551^{\text {水水水 }}$ & $0.444^{*} * *$ & $0.385^{\text {***** }}$ * & $0.329 * * *$ & $0.268^{* * *}$ & $0.218^{*}$ & $0.113^{*} *$ & $0.0774^{*} * *$ \\
\hline & $(0.257)$ & $(0.235)$ & $(0.141)$ & $(0.113)$ & $(0.102)$ & $(0.0875)$ & $(0.121)$ & $(0.110)$ & $(0.0513)$ & $(0.0254)$ \\
\hline \multirow[t]{2}{*}{$\mathrm{L}_{\mathrm{t}}^{*}$} & $0.165^{\text {*k }}$ & $0.347^{2}$ *水水 & $0.495^{\text {米水水 }}$ & $0.617^{*}$ *k* & $0.620^{\text {*2l } k_{k}}$ & $0.670^{* * * *}$ & $0.744^{* * \cdots *}$ & $0.847^{*} * *$ & 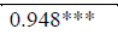 & $0.979^{* *}$ \\
\hline & $(0.0697)$ & $(0.0910)$ & $(0.164)$ & $(0.204)$ & $(0.222)$ & $(0.243)$ & $(0.205)$ & $(0.238)$ & $(0.258)$ & $(0.432)$ \\
\hline \multirow[t]{2}{*}{ Constant } & -0.0503 & $-0.304^{*}$ & 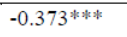 & $-0.368^{* 1 *}$ 米水 & 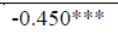 & 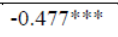 & 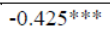 & $-0.401^{\text {米水 }}$ & 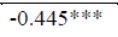 & $-0.347^{\text {水水 }}$ \\
\hline & $(0.0868)$ & $(0.172)$ & $(0.143)$ & $(0.141)$ & $(0.162)$ & $(0.170)$ & $(0.158)$ & $(0.161)$ & $(0.160)$ & $(0.162)$ \\
\hline Observations & 210 & 170 & 152 & 160 & 125 & 110 & 92 & 88 & 79 & 58 \\
\hline R-squared & 0.095 & 0.180 & 0.210 & 0.208 & 0.199 & 0.230 & 0.228 & 0.220 & 0.283 & 0.313 \\
\hline F-Statistic & 10.82 & 18.37 & 19.83 & 20.65 & 15.12 & 15.98 & 13.18 & 11.95 & 15.02 & 12.54 \\
\hline P-Value & 0.0000 & 0.0000 & 0.0000 & 0.0000 & 0.0000 & 0.0000 & 0.0000 & 0.0000 & 0.0000 & 0.0000 \\
\hline \multicolumn{11}{|l|}{ IPOs } \\
\hline & $\mathrm{IPO}+1$ & $\mathrm{IPO}+2$ & $\mathrm{IPO}+3$ & $\mathrm{IPO}+4$ & $\mathrm{IPO}+5$ & $\mathrm{IPO}+6$ & $\mathrm{IPO}+7$ & $\mathrm{IPO}+8$ & $\mathrm{IPO}+9$ & $\mathrm{IPO}+10$ \\
\hline \multirow[t]{2}{*}{$\mathrm{L}_{\mathrm{IPO}}$} & 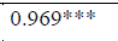 & 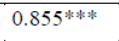 & $0.811^{\text {冰水 }}$ & $0.714^{\text {***** }}$ & 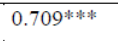 & 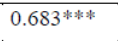 & $0.682^{*}$ 米隶 & 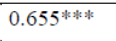 & 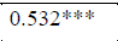 & 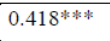 \\
\hline & $(0.199)$ & $(0.180)$ & $(0.183)$ & $(0.159)$ & $(0.155)$ & $(0.163)$ & $(0.163)$ & $(0.174)$ & $(0.149)$ & $(0.124)$ \\
\hline \multirow[t]{2}{*}{$\mathrm{L}_{\mathrm{t}}{ }^{*}$} & 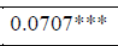 & 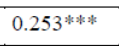 & $0.274^{*}$ 水水 & $0.309^{* * * 1 *}$ & $0.340^{\text {* } k^{2} \cdots}$ & $0.412^{*}$ *水水 & 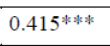 & 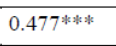 & $0.540^{* * * *}$ & 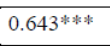 \\
\hline & $(0.0146)$ & $(0.0523)$ & $(0.0618)$ & $(0.0693)$ & $(0.0744)$ & $(0.102)$ & $(0.114)$ & $(0.129)$ & $(0.157)$ & $(0.142)$ \\
\hline \multirow[t]{2}{*}{ Constant } & 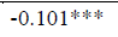 & 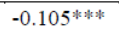 & $-0.0599^{\text {*水* }}$ & 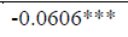 & 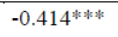 & 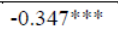 & 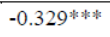 & 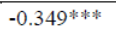 & 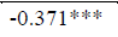 & $-0.328^{\text {永 }}$ \\
\hline & $(0.0315)$ & $(0.0333)$ & $(0.0199)$ & $(0.0198)$ & $(0.129)$ & $(0.121)$ & $(0.125)$ & $(0.127)$ & $(0.139)$ & $(0.125)$ \\
\hline Observations & 210 & 191 & 180 & 174 & 165 & 153 & 145 & 131 & 121 & 108 \\
\hline R-squared & 0.238 & 0.243 & 0.225 & 0.234 & 0.250 & 0.231 & 0.216 & 0.224 & 0.219 & 0.282 \\
\hline F-Statistic & 32.36 & 30.24 & 25.68 & 26.08 & 27.03 & 22.49 & 19.58 & 18.52 & 16.55 & 20.62 \\
\hline P-Value & 0.0000 & 0.0000 & 0.0000 & 0.0000 & 0.0000 & 0.0000 & 0.0000 & 0.0000 & 0.0000 & 0.0000 \\
\hline
\end{tabular}

Note: ${ }^{L_{i, I P O}}$ is the leverage ratio of firm i at IPO year and $L_{i, t}^{*}$ is firm i's target leverage at year t. *; **; *** indicates statistical significance at 1,5 , and $10 \%$. Standard errors are in parentheses.

According to the OLS estimates of the cumulative adjustment speed of RLBOs and public companies presented in table VII, on average, RLBOs adjust at a speed of 55\% four years following the initial public offering. Ten years following the initial public offering, RLBOs have reduced the gap between their current and target debt ratios. However, RLBOs adapt faster than public companies. Two years following the initial public offering, public companies adjust by $29 \%$ to the target, and the annual adjustment speed diminution during ulterior years. Nine years after the initial public offering, they only narrow almost $50 \%$ of the deviation from the target. The adjustment speed of the RLBOs is in accordance with our findings.

\section{Conclusion}

Our study compares the impact of market timing on the capital structure of RLBOs and public companies. We tested the generality and robustness of the theory of market timing based on a sample of 210 RLBOs listed between 1995 
and 2015 as well as a sample of 210 public companies listed between 1995 and 2015 and linked to RLBOs by size (turnover) and industry (based on the first two digits of the SIC code).

Market timing, measured by the historical M/B ratio, affects the capital structures of the two types of businesses differently. The impact of market timing measures namely, $\mathrm{MB}_{\text {efwa }}$ and $\mathrm{MB}_{\text {eqwa }}$ on the capital structure is different between RLBOs and public companies. In accordance with (Baker and Wurgler, 2002) and others, these measures have a significantly negative impact on the capital structure of the two types of business. The market timing effect on the capital structure of public companies is significant ten years following the IPO. However, the same result does not apply to RLBOs. Market timing measures do not significantly reflect the capital structure of RLBOs and are only significant during the second and third years following the IPO of LBOs. The $\mathrm{MB}_{\text {efwa }}$ coefficients are always negative, even if they are not significant. Furthermore, past share issues have no long-term impact on the capital structure of RLBOs since RLBOs rebalance the impact of market timing on their capital structures much more quickly and orient themselves toward the target debt ratio faster than their public counterparts. The results of the RLBOs are more in line with the trade-off theory. Overall, these results challenge the generality and robustness of the theory of market timing.

\section{Acknowledgments}

The author would like to express her gratitude to King Khalid University, Saudi Arabia for proving administrative and technical support.

The author would also like to thank the Labor of Economics and Applied Finance (LEFA), Institute of Higher Commercial Studies of Carthage, Tunisia, for supporting this research.

\section{References}

Alti, A. (2006). How persistent is the impact of market timing on capital structure?. The Journal of Finance, 61, 1681-1710. https://doi.org/10.1111/j.1540-6261.2006.00886.x

Alt1, A., \& Sulaeman, J. (2012). When do high stock returns trigger equity issues?. Journal of Financial Economics, 103, 61-87.

Baker, M., \& Wurgler, J. (2002). Market timing and capital structure. The Journal of Finance, 57, 1-32. https://doi.org/10.2307/2697832

Berger, P. G., Ofek, E., \& Yermack, D. (1997). Managerial entrenchment and capital structure decisions. Journal of Finance, 52, 1411-1438.

Bie, T., \& De Haan, L. de. (2007). Market timing and capital structure: Evidence for Dutch firms. De Economist, 155, 183-206.

Booth, L., Aivazian, V., Demirguc-Kunt, A., \& Maksimovic, V. (2001). Capital structures in developing countries. The Journal of Finance, 56, 87-130. https://doi.org/10.1111/0022-1082.00320

Bruinshoofd, W. A., \& Haan, L. (2012). Market timing and corporate capital structure: a transatlantic comparison. Applied Economics, 44, 3691-3703. https://doi.org/10.1080/00036846.2011.581211

Chang, X., \& Dasgupta, S. (2009). Target behavior and financing: how conclusive is the evidence?. Journal of Finance, 64, 1767-1796.

Chen, D.-H., Chen, C.-D., Chen, J., \& Huang, Y.-F. (2013). Panel data analyses of the pecking order theory and the market timing theory of capital structure in Taiwan. International Review of Economics \& Finance, 27, 1-13. https://doi.org/10.1016/j.iref.2012.09.011

Chen, L., \& Zhao, X. (2006). On the relation between the market-to-book ratio, growth opportunity, and leverage ratio. Finance Research Letters, 3, 253-266.

Doukas, J. A., Guo, J., \& Zhou, B. (2011). Hot' Debt Markets and Capital Structure. European Financial Management, 17, 46-99. https://doi.org/10.1111/j.1468-036X.2010.00549.x

Elsas, R., Flannery, M. J., \& Garfinkel, J. A. (2014). Financing major investments: Information about capital structure decisions. Rev Finance, 18, 1341-1386. https://doi.org/10.1093/rof/rft036

Fama, E. F., \& French, K. R. (2002). Testing trade-off and pecking order predictions about dividends and debt. The Review of Financial Studies, 15, 1-33. https://doi.org/10.2307/2696797

Flannery, M., \& Rangan, K. P. (2006). Partial adjustment toward target capital structures. Journal of Financial Economics, 79, 469-506. 
Frank, M., \& Goyal, V. (2003). Testing the pecking order theory of capital structure. Journal of Financial Economics, 67, 217-248.

Graham, J. R., \& Harvey, C. (2001). The theory and practice of corporate finance: evidence from the field. Journal of Financial Economics, 60, 187-243.

Harris, M., \& Raviv, A. (1991). The theory of capital structure. Journal of Finance, 46, 297-355.

Hovakimian, A. (2006). Are observed capital structures determined by equity market timing?. Journal of Financial and Quantitative Analysis, 41, 221-243.

Hovakimian, A., Opler, T., \& Titman, S. (2001). The debt-equity choice. Journal of Financial and Quantitative Analysis, 36, 1-24.

Huang, G., \& Song, F. M. (2006). The determinants of capital structure: Evidence from China. China Economic Review, 17, 14-36.

Huang, R., \& Ritter, J. (2009). Testing theories of capital structure and estimating the speed of adjustment. Journal of Financial and Quantitative Analysis, 44, 237-271.

Kayhan, A., \& Titman, S. (2007). Firms' histories and their capital structures. Journal of Financial Economics, 83, $1-32$.

Köksal, B., \& Orman, C. (2015). Determinants of capital structure: evidence from a major developing economy. Small Bus Econ, 44, 255-282. https://doi.org/10.1007/s11187-014-9597-x

Leary, M. T., \& Roberts, M. (2005). Do Firms Rebalance Their Capital Structures?. Journal of Finance, 60, 2575-2619.

Mahajan, A., \& Tartaroglu, S. (2008). Equity market timing and capital structure: International evidence. Journal of Banking \& Finance, 32, 754-766. https://doi.org/10.1016/j.jbankfin.2007.05.007

Myers, S. C. (1984). The Capital Structure Puzzle. The Journal of Finance, 39, 574-592. https://doi.org/10.1111/j.1540-6261.1984.tb03646.x

Myers, S. C. (1977). Determinants of corporate borrowing. Journal of Financial Economics, 5, 147-175. https://doi.org/10.1016/0304-405X(77)90015-0

Rajan, R., \& Zingales, L. (1995). What do we know about capital structure? Some evidence from international data. Journal of Finance, 50, 1421-1460.

Scott, J. H. (1977). Bankruptcy, secured debt, and optimal capital structure. The Journal of Finance, 32, 1-19. https://doi.org/10.2307/2326898

Shyam-Sunder, L., \& Myers, S. C. (1999). Testing static tradeoff against pecking order models of capital structure. Journal of Financial Economics, 51, 219-244.

Warner, J. B. (1977). Bankruptcy Costs: Some Evidence. The Journal of Finance, 32, 337-347. https://doi.org/10.2307/2326766

Wiwattanakantang, Y. (1999). An empirical study on the determinants of the capital structure of Thai firms. Pacific-Basin Finance Journal, 7, 371-403. https://doi.org/10.1016/S0927-538X(99)00007-4

Zavertiaeva, M., \& Nechaeva, I. (2017). Impact of market timing on the capital structure of Russian companies. Journal of Economics and Business, 92, 10-28.

\section{Copyrights}

Copyright for this article is retained by the author(s), with first publication rights granted to the journal.

This is an open-access article distributed under the terms and conditions of the Creative Commons Attribution license (http://creativecommons.org/licenses/by/4.0/). 